Stanhridge pit, and were presented to the Woodwardian Musenm by $\mathrm{Mr}$. H. Coningshy; they are angular blocks, $10 \times 6 \times 6$ and $7 \times 7 \times 6$ inches in size, and weigh 16 lbs. and 13 lbs. respectively. Attached to their surface are numerous specimens of Plicatula sigillina, Woodw., and Spondylus striatus (Sow.), and small concretions of iron pyrites. The quartzite is rather coarse-grained, and was originally a quartz-conglomerate.

H. Woons.

\title{
NOTE ON THE ERRATIC BLOCKS OF POLARIS BAY AND OTHER LOCALITIES IN NORTH GREENLAND.
}

SIR,-I should like to place upon record a statement $I$ ought to have published years ago, but which at the time the subject was fresh I thought of too little moment to record. Since then I notice that what I believe to be an erroneous deduction, has been cited by authors of eminence as a fact, without any qualification. The late Dr. Emil Bessels, when in Hall Land, North Greenland, with the "Polaris" Expedition, noticed that the land in the vicinity of the "Polaris". winter quarters was strewn up to elevations of over 1,000 feet with erratic ice-borne boulders, entirely distinct in character from the rocks in situ. Bessels, who was a man of high attainments, and a good observer, misled, I believe, by many of these erratics having a superficial resemblance in composition to rocks found in South Greenland, made the sweeping assertion ${ }^{1}$ that these erratics came from South Greenland; and that the current and ice-drift in Smith Sound and Robeson Channel, at a former period when these erratics were dispersed, had been from south to north, and not from north to south as is the case to-day. When I sojourned in Grinnell Land, during 1875-76, I was aware of Bessels' opinion, and made many observations on the boulders we met with, and on their distribution. I found them as Bessels described, even on the bigher altitudes uncovered by snow, notably on Dean Mount, near the winter quarters of the "Alert," in $82^{\circ} 27^{\prime}$ N., at an altitude of 1,200 feet. I observed, however, what Bessels seems to have overlooked, that boulders of the same character were strewn over hillsides and in the valleys down to the present sea-level, and that on some ancient sea-beach at a hundred feet of altitude the stranded boulders were lying under precisely the same conditions as the boulders that now rest on the seashore of to-day, and which have been recently stranded. Grinnell Land is an area of very rapid elevation, and it is only reasonable to argue that the agent that strands the ice-worn boulder to-day on the fore-shore of Grinnell Land is the same as placed the boulders at an altitude of 1,200 feet when that point stood at sea-level. The agent that grounds the erratic of to-day is the ice-raft of the palæocrystic sea, and Bessels was certainly mistaken when he ascribed the origin of these rocks to South Greenland, and to clench his argument had to invoke a change in oceanic circulation to account for the presence of the boulders on the shores of the Polar Ocean. Bessels made a strong point that

1 Bull. de la Soe. Geog. Paris, p. 298, March, 1875. U.S. Naval Report, 1873, p. 548. Arctic Manual, p. 553, 1875 . 
one of the most marked characteristics of some of these boulders was their containing large garnets, similar to those in a rock found in the neighbourhood of Fiskernäs, in South Greenland. It is perfectly correct that some of the boulders I met with in Grinnell Land were of garnetiferous gneiss, and the difference between them and the blue Silurian limestone or dark Azoic slate, the rock in situ, on which they were lying, could hardly fail to attract attention. From Lady Franklin Bay, on the west side of Robeson Channel, as far north as Cape Joseph Henry, I did not meet with this garnetiferous gneiss as a rock of the country. It does not occur as such in Hall Land, neither do I think it can be found in situ along the lands visited by Aldrich in his journey along the north shore of Grant Land, nor on the northern shores of Greenland traversed by Beaumont, Lockwood, Brainard, Peary, and Astrup, for this rock is of such a striking character that such intelligent observers as I have mentioned could not well have passed over it withont remarking its garnetiferous structure. There was a fine example of an ice-rounded boulder of this remarkable rock lying stranded a little above highwater line, not far from the "Alert's" winter quarters, in $82^{\circ} 27^{\prime} \mathrm{N}$. Fortunately I brought away with me fragments of this boulder, which are now in the British Museum; I am informed that the fragment is a "coarse-grained aggregate of large garnets, orthoclase, cordierite, fibrolite, and quartz, with a little biotite. A peculiar feature of the rock is the enclosure of rounded quartz crystals in the felspar. It is probably a garnetiferous cordierite-fibrolite gneiss, but the fragment is too small to show the foliation."

The conclusion $I$ arrive at is, that this erratic boulder and its fellows, scattered over the shores of Grinnell Land and North Greenland, cannot by any possibility have been derived from South Greenland, and floated up through Davis Strait, Baffins Bay, Smith Sound, and Robeson Channel, to the Polar Sea. Such a supposition is as much at variance with fact, as to cast a bladder into the sea at Cape Clear, and assure us that it reached the West Indies; and I cannot understand how a man of Bessels' ability could formulate such a theory. It is far more reasonable to presume that these erratics are derived from some land within the unknown region of the Polar area. If so, the land that produces them must support glaciers, for these ice-worn bonlders have passed through the mill of a glacier, to give them their present shape and wear. There can be little doubt that the drift-wood stranded on the shores of the Polar Ocean, along the coast of Grinnell Land, is derived from the great rivers of Siberia, and the same drift and current that transports it is equally capable of drifting ice-borne erratics from unknown Polar lands.

H. W. Feilden, Colonel R.A.

West House, Welds, Norfolk.

EXPANSION THEORY OF MOUNTAIN EVOLUTION.

Srr,-Mr. Davison, in a "Second Note on the Expansion Theory of Mountain Evolution,". quoting Prof. Le Conte, restates what he thinks to be a fundamental oljection to the expausion theory. 